\title{
DESIGNING OF A SOLAR POWERED VEHICLE UTILIZING VANADIUM REDOX FLOW BATTERY
}

\section{DR. KAMAL KISHORE PATHAK}

Department of Mechanical Engineering, Government Polytechnic Sheikhpura, Bihar

\section{ABSTRACT}

This paper offers the basics of utilization of vanadium oxidation-reduction flow batteries in solar powered vehicles, mainly cars. The two folded objective of this research is to use a source of energy that is renewable in nature to run the automobiles and designing of the solar powered system in such a way to store the unused solar energy. Moreover, the feasibility of using vanadium redox flow battery (VRFB) for refueling of the system is also presented. Overall, a environment friendly and cost effective system has been generated utilizing solar energy.

KEYWORDS: Renewable Energy, Vanadium Redox Flow Battery, Solar Powered Car

Received: Jun 06, 2020; Accepted: Jun 26, 2020; Published: Aug 25, 2020; Paper Id.: IJMPERDJUN2020876

\section{INTRODUCTION}

The growing limitations of fuel options and increasing energy demand put the world to look for other fuels alternatives. The main area of the fuel consumption, automobiles, is therefore working towards the direction of switching the conventional fuels with other available options. One of the recent areas of research for them is the applicability of solar energy in automobiles. Thus several researches have been done on solar-powered vehicles. In solar powered vehicles, the sun is the main source of energy that is utilized for producing electricity, which is needed for running devices. These kind of solar powered vehicles are not very common in India, and still researches have been going on in the same direction. Although solar powered vehicles, basically cars, have various advantages such as they have zero emissions thus eco-friendly in nature, and they have no fuel costs, however, certain limitations still persists such as energy storage, design challenges and poor practicability [1][2][3]. Dealing with all these limitations is necessary for making solar powers cars globally available. Both experimental as well as modeling work are going on with full pace to developed this system Taking a step in the same direction, this paper mainly deals with the energy storage of the solar powered vehicles. In this paper we will firstly take a glimpse of main components of the system, working of the system, feasibility of vanadium oxidation-reduction flow batteries as energy storage and the creditability of this system for making itself globally available. Figure 1 depicts the working of solar powered vehicles. 


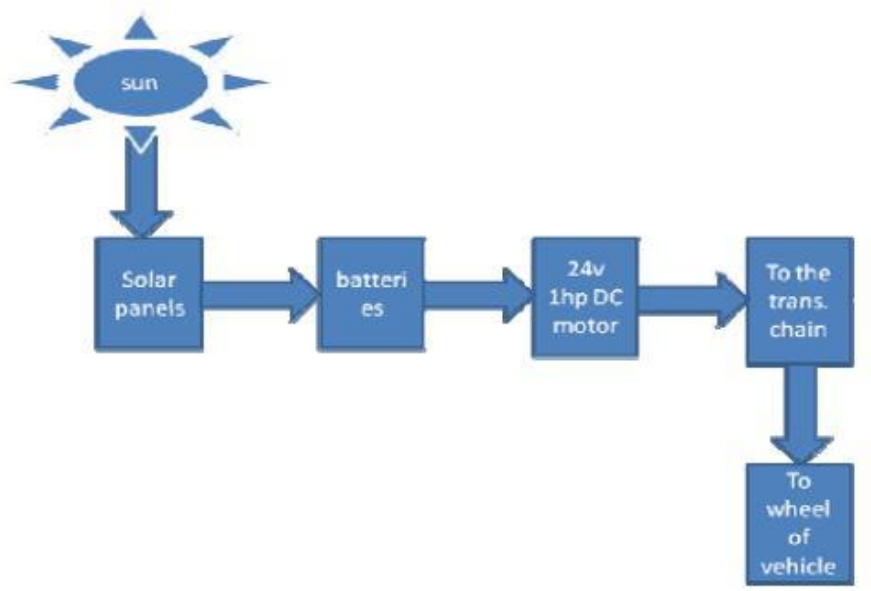

Figure 1: Working of Solar Powered Vehicles.

\section{BASICS OF SOLAR POWERED CARS}

Figure 2 shows a overview of components of solar powered cars. The main source of energy for the vehicle is the solar radiations. The solar energy is stored by the solar panels and then it is converted to electrical energy. The generated electrical energy is provided to the batteries to charge them and then use them to operate the motor. The shaft of the motor is further connected to rear wheel of car with the help of chain sprocket. Initially, the batteries are fully charged by the external source and thereafter they are charged by the panels. This resulted in completing the batteries chargingdischarging cycle. The main components of a solar powered car are as follows [4][5]:

- Solar Array - Its purpose is to collect the energy of sun and then its conversion to electrical energy.

- $\quad$ Power trackers- It is used to achieve the proper voltage to store it in batteries.

- $\quad$ Batteries- It is used for stirring power.

- Motor controller-Its main purpose is to adjust the power input.

- Electric motor- It is the main component which drives the system.

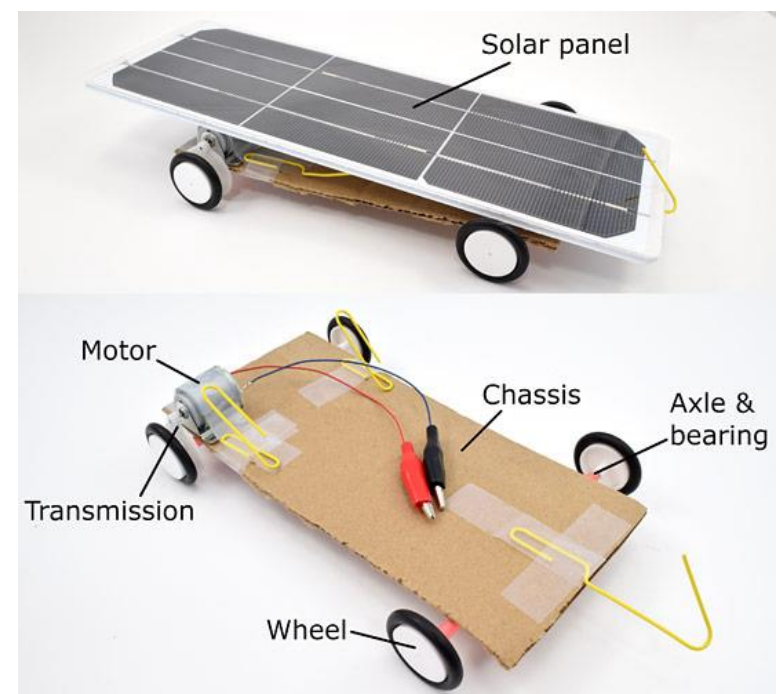

Figure 2: Main Components of Solar Powered Vehicles. 


\section{WORKING OF SOLAR POWERED CAR}

Working of a solar powered car is easy to understand. When the throttle pedal operated from electricity is throttled, the controller controls and transmits current and voltage required to the engine. The battery is used to measure the required current. Here, solar panels are used to charge the batteries. The solar panel gets solar radiation and charges the batteries. The solar panel comprises of PV (photovoltaic) cells which observes heat from sunlight and changes over it as current. The engine shaft than rotates and thus making the drive shaft to rotate. The drive shaft rotates the wheel and thus the vehicle moves. No emission is generated by this process and it is an Ecofriendly vehicle. When the vehicle is needed to stop, brake pedal is pressed which is associated as an arrangement with master cylinder and thus related with the calliper to stop the vehicle. Forward and reverse switch is utilized to run the car in forward and reverse direction [6].

Now in order to improve the design of solar powered vehicle, we can implement Vanadium redox flow battery (VRFB) as an energy storage device so as to store the extra amount of unused solar energy and utilizing this stored energy when required.

\section{VANADIUM REDOX FLOW BATTERY AS AN ENERGY STORAGE}

The random distribution and variation of the solar radiations limits the proper working of solar powered vehicle. It indicates that the vehicle cannot run when there is no sufficient solar radiation. Thus, an efficient energy storage system is therefore needed for proper accumulation, transmission and distribution of energy generated from Sun. Compressed air energy storage, pumped hydro energy storage, and flywheel energy storage are some of the energy storage technologies being used nowadays. Electrochemical energy storage devices (ESS) are best suitable among these technologies owing to its fast response time, high energy efficiency, and low standby losses. One of the best encouraging technology among all ESS devices (for e.g, Fuel cells, batteries and redox batteries, etc.,) is vanadium redox flow battery (VRFB). The aptness of vanadium to present in four divergent oxidation states in the solution gives vanadium oxidation-reduction flow batteries an advantage over the other redox flow batteries [7][8]. The success of this technology also gives credence to some of its other idiosyncratic characteristics, e.g,

- Long discharge times,

- High energy efficiencies,

- Minimum waste disposal as the use of the same element vanadium in its four oxidizing states avoid problems related to cross-contamination,

- Minimum environmental effect during production and disposal as compared to other electrochemical systems that utilize heavy metals such as cadmium, lead, zinc and nickel, and

- Capability of fully getting discharged without harming the battery

Another important characteristic of the VRFBs is their decoupled energy and power densities. With this feature, VRFBs can be easily distinguished from other conventional batteries for example lead-acid battery and lithium-ion battery.

The unused energy generated from the sun is converted to electrical energy. The generated electrical energy is being fed to the vanadium redox batteries that get charged and then can be further used to run motor when required. 
Initially, the batteries are fully charged by the external source and thereafter they are charged by the panels. This resulted in completing the batteries charging-discharging cycle.

\section{WORKING OF VANADIUM REDOX FLOW BATTERY}

VRFB is an electrochemical device which transmutes the chemical energy of the electrolytes into electric current and vice versa. It is a large stationary electricity storage systems with many potential applications such as, for yielding continuous power supply, peak shaving, load leveling, and for emergency backups. The first VRFB was developed in 1980 by Maria Skyllas- Kazacos \& co-workers at University of North South Wales in Australia. Figure 3 represents a schematic of VRFB. It consists of two electrodes (termed as positive and negative electrode), a separator, two current collectors, two electrolyte reservoirs, and two peristaltic pumps. The electrodes which are typically made up of carbon or graphite felt materials provide active sites for the electrochemical reactions. Both tanks contain electrolytes having vanadium salts, i.e, $\mathrm{V}^{+2}$ and $\mathrm{V}$ ${ }^{+3}$ in the negative electrode $\& \mathrm{~V}^{+4}$ and $\mathrm{V}^{+5}$ in the positive electrode, dissolved in aqueous solution of sulfuric acid. Separators are made up of ion exchange materials which selectively allow transport of protons and prevent direct mixing of electrolytes at the two electrodes. The liquid electrolytes are stored in external reservoirs and consistently passed through the electrodes with pumps during charge and discharge, hence justifying the name, "flow battery". During discharge, the V ${ }^{+2}$ ions present at the -ve electrode get oxidized as a result of the electrochemical reaction and transformed into $\mathrm{V}^{+3}$ along with the release of an electron as demonstrated in Eq. 1. The released electrons flow in external circuit \& protons flow through the separator to reach at the positive electrode where they combine with $\mathrm{V} \mathrm{O}_{2}{ }^{+}$through electrochemical reaction to form $\mathrm{V} \mathrm{O}^{2+}$ ion as expressed in Eq. 2 [9][10]. The reactions occuring in the negative \& positive electrode, where $\rightarrow$ and $\leftarrow$ arrow indicates charging and discharging, respectively, are as follows:

Negative Electrode:

$$
\mathrm{V}^{3+}+e^{-} \underset{\text { discharge }}{\stackrel{\text { charge }}{\rightleftharpoons}} \mathrm{V}^{2+}
$$

Positive Electrode:

$$
\mathrm{VO}^{2+}+\mathrm{H}_{2} \mathrm{O} \underset{\text { discharge }}{\stackrel{\text { charge }}{\rightleftarrows}} \mathrm{VO}_{2}^{+}+e^{-}+2 \mathrm{H}^{+}
$$

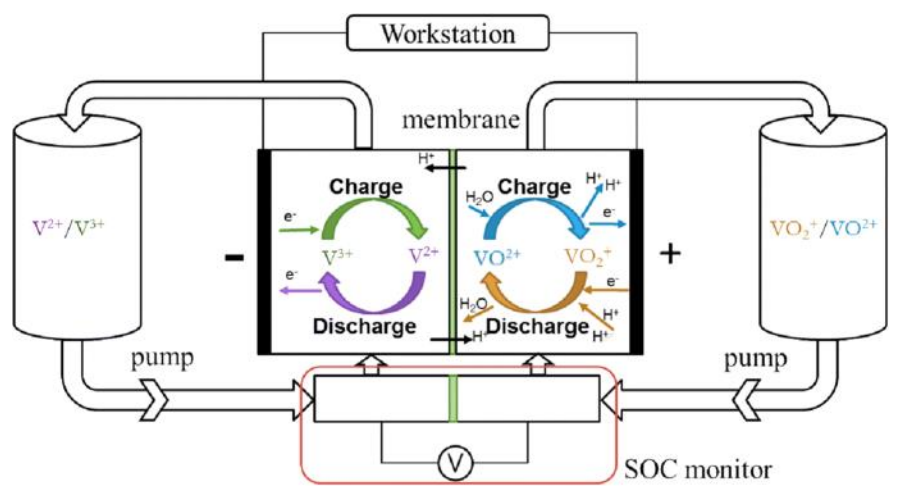

Figure 3: Schematic of Vanadium Redox Flow Battery. 


\section{MORE APPLICATION OF VRFB IN SOLAR POWERED CARS}

Apart from utilizing vanadium oxidation-reduction flow battery as a storage of unused solar energy, it can also be used for rapid refueling. Figure 4 shows a solar powered car with VRFB as a refueling system. In this refueling flow battery system, electrolyte is re-energized continually in refueling pump by solar energy. This unique capability of solar powered system with refueling can overcome the demerits of advanced batteries of having high cost. The other benefit of using this system is its environmental friendly and economical nature.

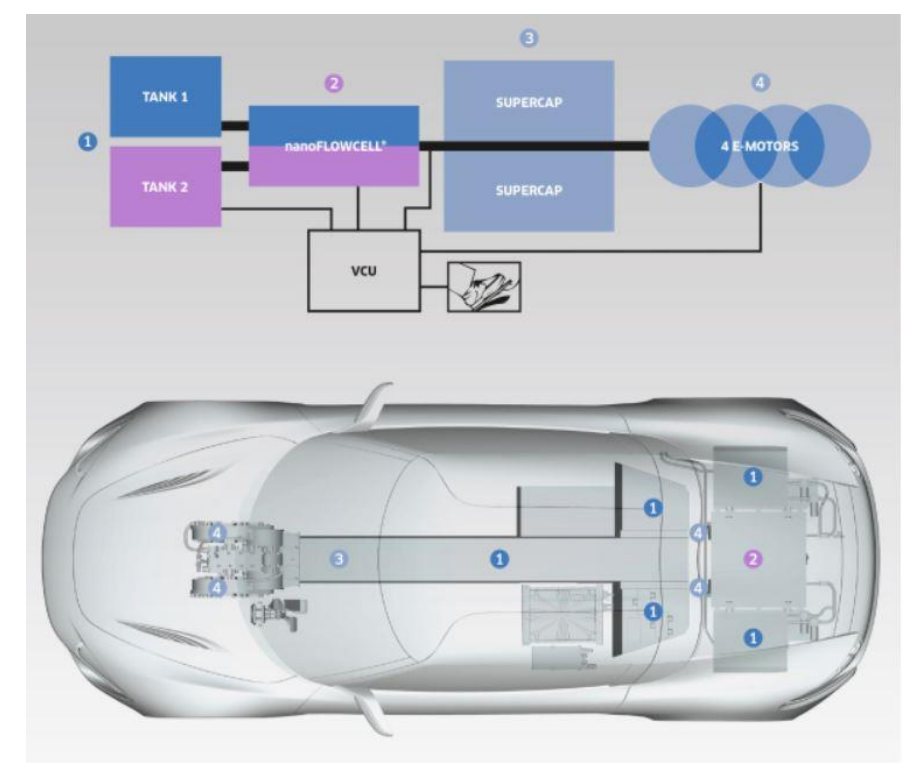

Figure 4: Refueling of Solar Powered Cars.

\section{CONCLUSIONS}

This paper discusses a cost effective system by utilizing solar energy, renewable energy source, is developed. The absence of any harmful gas emission made this system a blessing for the environment. This paper begins with explaining the working principle of solar powered cars. The paper further discusses the advantages of using a vanadium oxidationreduction flow battery. The random distribution and fluctuating nature of solar energy can be handled by using vanadium redox flow battery; used for storing the unused solar radiation.

This paper further provides the feasibility of combining the storage of energy in form of VRFB system with the solar powered vehicles. Moreover, an addition advantages of using vanadium oxidation-reduction flow battery as a refueling system is also being discussed. We concluded that the combined system developed solves many environmental problems and it is the best pollution free method available. In spite of some of the limitations of this system, researchers have been going and soon it will be possible to see solar powered vehicles incorporated with VRFB everywhere in the country.

No doubt, this paper has provided a more profound knowledge about utilizing a energy storage device such as VRFB together with solar vehicle. However, there are multiple physics or phenomena which are yet to be considered. So, the identified future work is to develop a mathematical model for this combine system. 


\section{REFERENCES}

1. Barry, Courtney. "Here They Come, as Fast as the Sun Will Carry Them." The New York Times. Oct. 22, 2003. (June 27, 2008). Retrieved from: http://query.nytimes.com/gst/fullpage.html?res=940CE5D71 43FF931A15753C1A9659C8B63

2. Derbyshire, David. "Vaccum cleaner king James Dyson plans solar-powered car that travels hundreds of miles." The Daily Mail. June 22, 2008. (June 27, 2008). Retrieved from: http://www.dailymail.co.uk/sciencetech/article-1028490/Vac uumcleaner-king-James-Dyson-plans-solar-powered-car-tra vels-hundreds-miles.html

3. “Distance Races.” Solar Car Racing, 2014. Retrieved from: http://en.wikipedia.org/wiki/Solar_car_racing

4. "Energy Savers." Office of Energy Efficiency and Renewable Energy. April 7, 2004. Print.

5. "High Efficiency Environment Friendly Flexible Solar Array.” Shenzhen Sanyifeida Technology Co., 2014. Retrieved from: http://syfdsolar.en.made-in-china.com/product/lXdJxFWPAf ky/China-High-Efficiency-Environment-Friendly-Flexible-S olarArray.html

6. "High Efficiency Solar Module." Shenzhen Sanyifeida Technology Co., 2013. Retrieved from: http://www.syfd solar.com/en/Productsinfo.aspx?ProductsID $=119 \&$ CateId $=144$

7. E. Sum and M. Skyllas-Kazacos. A study of the $v(i i) / v(i i i)$ redox couple for redox flowcell applications. Journal of Power Sources, 15(2):179\{190, 1985.

8. M. Rychcik and M. Skyllas-Kazacos. Characteristics of a new all-vanadium redox flow battery. Journal of Power Sources, 22(1):59\{67, 1988.

9. Ke-Long Huang, Xiao gang Li, Su qin Liu, Ning Tan, and Li quan Chen. Researchprogress of vanadium redox ow battery for energy storage in china. Renewable Energy,33(2):186\{192, 2008.

10. Xiangkun Ma, Huamin Zhang, Chenxi Sun, Yi Zou, and Tao Zhang. An optimal strategyof electrolyte ow rate for vanadium redox ow battery. Journal of Power Sources, 203:153, 2012.

11. Kurczewski, Nick. "How Eclectic!"AutoWeek. June 18, 2007. (June 27, 2008). Retrieved from: http://www.autoweek.com/apps/pbcs.dll/article?AID=/20070 612/FREE/70608014

12. Letendre, Steven E. "Solar Vehicles at Last?" Solar Today. May/June 2006. U.S. Department of Energy. Print.

13. "Solar car driver determined to reach Canada's land of midnight sun." CBC News. June 26, 2008. (June 27, 2008). Retrieved from: http://www.cbc.ca/canada/north/story/2008/06/26/solar-car.h tml ref=rss

14. “Solar Car Project.” Stanford, 2014. Retrieved from: http://solarcar.stanford.edu/

15. “Sunpower-solar-panels.” Ebay. Retrieved from: http://www.ebay.com/bhp/sunpower-solar-panels.

16. “Sunpower X-Series Solar Panels.” Free Clean Solar, 2014. Retrieved from: http://www.freecleansolar.com/SunPower-XSeries-Solar-Pa nels-s/4562.htm

17. Arwa Wafiq Hussein \& Mohamed Walid Ahmed, "Solar Energy: Solution to Fuel Dilemma", IMPACT: International Journal of Research in Engineering \& Technology (IMPACT: IJRET), Vol. 2, Issue 8, pp. 99-108

18. Gajendra R. Patel, Dilip B. Patel \&Kinjal M. Paghdal, “Analysis of P\&O MPPT Algorithm for PV System “, International Journal of Electrical and Electronics Engineering (IJEEE), Vol. 5, Issue 6, pp. 1-10

19. Zatir Sara \& Benkoula Sidi Mohammed El Habib, "The Impact of Renewable Energy in Urban Planning Instruments the Case of the PDAU “, IMPACT: International Journal of Research in Engineering \& Technology (IMPACT: IJRET), Vol. 2, Issue 7, pp. 123-126 
20. Monika Shekhar Gupta \& Y. P. Singh, "Climate Change and Public Awareness “, BEST: International Journal of Humanities, Arts, Medicine and Sciences (BEST: IJHAMS), Vol. 3, Issue 10, pp. 113-124

\section{AUTHORS PROFILE}

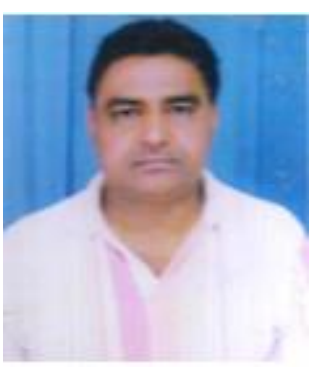

Dr. Kamal Kishore Pathak is currently working as a Lecturer (Selection Grade) at Government Polytechnic Sheikhpura (Bihar). He did his B.Sc. Engineering in Mechanical Engineering from Bihar College of Engineering, Patna in 1987. Since then he has been engaged in teaching and research. He obtained his M.Tech and Ph.D. from B.R.A. Bihar University, Muzaffarpur. He has wide exposure in the Mechanical Engineering field and has 30 years of experience in teaching engineering students. He is the life time member of Indian Society for Technical Education (ISTE) and also the author of the book "Strength of Materials (Mechanics of Solids)" ISBN: 978-8193003756, First Edition, Nexus Publication, Patna, 2017. 

